\title{
Prospects of Shotcrete Shaft Lining for Underground Sustainable Mining
}

\section{Binay Kumar Samanta ( $\nabla$ iitism.bks@outlook.com )}

Department of Mining Engineering Indian Institute of Technology (Indian School of Mines), Dhanbad https://orcid.org/0000-0003-3322-1355

\section{Upendra Kumar Singh}

IIT (ISM): Indian Institute of Technology

\section{Research}

Keywords: Rock properties, Shaft Lining, Deep pits, Cost Saving, Pre-split blasting, Shotcrete, Programing, Output Run

Posted Date: January 16th, 2021

DOI: https://doi.org/10.21203/rs.3.rs-139133/v1

License: (c) (1) This work is licensed under a Creative Commons Attribution 4.0 International License. Read Full License 


\title{
PROSPECTS OF SHOTCRETE SHAFT LINING FOR UNDERGROUND SUSTAINABLE MINING
}

\author{
Binay Kumar Samanta1 and Upendra Kumar Singh2 \\ Department of Mining Engineering \\ Indian Institute of Technology (Indian School of Mines), Dhanbad 826004D \\ Email: iitism.bks@outlook.com, singhuk@iitism.ac.in
}

\begin{abstract}
Investment in underground mining is coming down all over the world, but deep reserves are available for extraction. Conventional sinking and lining of mine shaft projets or pits for winding men and materials from deep underground mines are getting very costly and being deferred. We found Polish technology of Shaft sinking with monolithic mining very efficient in Sudamdih, Monidih and Satgram projects in India. Russian collaboration for Jhanjra for shaft sinking and mine construction for large mine has been successful. Underground production is declining world over, while remaining reserves are at greater depths. Designing and coding original model programs by collecting actual field data to run the programs to determine cost benefit at different depths with standard diameters has been done. Most companies are avoiding deep mining projects, because of exorbitant cost of shaft sinking. As per experience of the researcher, pre-split blasting and shotcrete lining can be much faster and cheaper. So model programs have been designed and run with practical field cost and technical data, as exemplified in this paper. Future of deep pit mining will be assured with successful adoption of the method in projects, especially through hard rock strata
\end{abstract}

KEYWORDS: Rock properties; Shaft Lining; Deep pits; Cost Saving, Pre-split blasting; Shotcrete; Programing; Output Run

\section{INTRODUCTION}

Objective of the research is to determine the most cost effective and fast sinking and lining of underground mine shafts. Various studies of geo-mechanical properties of Indian coal measure rocks reveal that compressive, tensile and shear strengths are 2 to 3 times higher than European coal-measure rocks. In India during British rule, hundreds of shafts were sunk in Jharia, Raniganj and other coalfields, without any lining, except brick walling up to shaft collar or rock-head. Some of these shafts are winding men or materials even today, with precautions of checking and occasional side dressing or side bolting or shotcrete.

In the year 2018-19, out of CIL total coal production of 606.89 MT, production from underground mines was 30.48 MT (19.91\% share). Lined shafts made mandatory by DGMS Circular, for man and material winding. In India with progressive depletion of shallow deposits there is no option but to deepen the existing shafts or sink new shafts, to mine coals and reduce import burden.

The present updated geological coal resource of the country is 319.02 billion tons as on 01.04.2018 for coal seams of $0.90 \mathrm{~m}$ and above in thickness and up to $1200 \mathrm{~m}$ depth from surface. Most of the mines are working to a depth below $300 \mathrm{~m}$ and mining deep seams, where about $70 \%$ of remaining coal reserves is present, but are shelved for higher cost.

Some high capacity shafts, with monolithic concrete lining, rigid guides and skip winding in the sixties were made. For example at Sudamdih, Moonidih in Jharia coalfields and Banki, Surakhachar in Western coalfields and in eighties ,Satgram, JKNagar, Jhanjra of Raniganj coalfields and Pootkee, Bhalgora of Jharia coalfields and others (Samanta BK.1999). Exorbitant cost of construction of such shafts, followed by heavy losses suffered by these mines, are the reasons of deferment of deep mining projects.

\section{MATERIALS AND METHODS}

Existing method of shaft lining is pouring monolithic concrete behind a centralized shuttering suspended from mechanized winches from surface. Authors propose to replace with fiber reinforced shotcrete for thin lining after pre-split blasting, which gives smooth surface. In Indian condition, shaft lining is only required 
for protecting against weak or brecciate zones, slips, faults. The circular shape is the most stable for pits, as per theory of structures and sandstone is quite competent rock (Samanta B.K.2003). Actual data of existing operations from shaft lining have been gathered and shotcrete lining proposed method cost estimated. The authors have developed a model program 'scl' to determine cost benefit of fiber reinforced shotcrete compared to monolithic concrete lining in shaft lining.

Fiber-reinforced concrete (FRC) is concrete containing fibrous material (Kumar D, Behera PK, Singh UK 2003), which increases its structural integrity. It contains short discrete fibers that are uniformly distributed and randomly oriented. Shotcrete is also known as sprayed concrete and is being increasingly applied in thickness up to about $75 \mathrm{~mm}$, to rock surface, with concrete chips up to $12 \mathrm{~mm}$. Materials for shotcrete include Calcium Chloride, Sodium Hydroxide, and Sodium Silicate for accelerating setting and resins for sticking to the wall.

From the theory of elasticity, compressional (or longitudinal) P-wave velocity (vp) is related to the elastic modulus (Es), and the density ( $\rho$ ) of the material as,

$\mathrm{vp}=(\mathrm{Es} / \rho)^{1 / 2}$ or $\mathrm{Es}=\rho \mathrm{vp}^{2}$.

where $\rho$ in $\mathrm{g} / \mathrm{cm} 3$, and vp in $\mathrm{km} / \mathrm{s}$, then Es in GPa $(109 \mathrm{~N} / \mathrm{m} 2)$. The elastic modulus estimated. It is different from the modules obtained by the uniaxial compression tests. The value of the seismic modulus is generally slightly higher than the modulus determined from static compression tests (Ahmadi MH, Molladavoodi H, Vásárhelyi B, Davarpanah SM, Dibavar BH 2019)

Shaft design is by testing of rocks along the section of shaft, samples gleaned from the cores of taken from borehole in the designed location. Test is made (Mehmet Sari 2018) on cylindrical samples, usually of dimensions length: diameter of 1:1, after grinding and lapping of the end surfaces. Static tests are comparative simpler and cheaper to perform, such as Young's Modulus = axial stress/ strain, Modulus of Rigidity $=$ Shear stress/shear strain, Poisson's Ratio = Lateral strain/longitudinal strain etc. Comparison of dynamic and static properties of sandstone, given by Roberts of English coal measure rocks, is shown in Table 1.

The responsive behavior of the shotcrete lining (Singh UK and Singh, 2011) can be analyzed within the convergence-confinement method. The response curve for the shotcrete support can be calculated as: - pi= $\mathrm{kc} \Delta \mathrm{us}$, where $\Delta \mathrm{us}$ is the deformation of the shotcrete and $\mathrm{kc}$ is the stiffness of the shotcrete, given by $\mathrm{kc}=$ $\mathrm{Ecrr}^{2}-(\mathrm{r}-\mathrm{ts})^{2}(1+v c)\left[(1-2 v c) \mathrm{r}^{2}+(\mathrm{r}-\mathrm{ts})^{2}\right]$, in which ts is the shotcrete thickness. The relationship given in Equation. is valid until $p_{\max }$ is reached. $p_{\max }$ can be calculated as $p_{\max }=12 \sigma c s\left[1-(r-t s)^{2} r^{2}\right]$, where the $\sigma c s$ is the uniaxial compressive strength of the shotcrete.

Types and properties of strata determine the shaft lining methods. Mud brick, Cement brick, steel tubbings, monolithic, RCC are the most usual methods. In case of very weak strata, cementation or freezing techniques are applied before lining. Shear strength could be obtained (Hoek E, Marinos P, Marinos V. 2005) from Moh's envelope or by cylindrical punch into rock specimens and is given by $\mathrm{S}=\mathrm{W} / \mathrm{p} * \mathrm{~d} * \mathrm{t}$, where, W-punch load at failure, $d$-punch $\varphi$, and t-thickness of rock disc. There are various other methods sometimes used for rock hardness tests like Vickers's, point load, Shore Scleroscope, Schmidt Rebound Hammer etc. and Impact tests on rocks like Hopkinson's bar, Protodeakonov Index, Cerchar Index, Specific Energy Index etc. Cage or skip movement in shafts exert dynamic stress on shaft walls, (Sarkar BN, Samanta BK 1993) especially with rigid guides. Tests of concrete blocks done at CIMFR (Central Institute of Mining \& Fuel Research) as shown in Table 1.

Static properties of rocks are usually lower than dynamic ones. It has also been observed that horizontal stress is much less, compared to vertical stress, in shaft walls. Permissible stress (in kg/sq.cm) on concrete, according to National Building Code, 1970 of Indian Standards Institution, New Delhi, with Factor of Safety of 3 is given in Table 2 .

Tests of concrete blocks at CIMFR (Central Institute of Mining \& Fuel Research) showed Bulk Density- 2.14 g/cc; Young's Modulus- 0.5 GPa; Compressive strength- $8.26 \mathrm{KPa}$; Tensile Strength- $0.95 \mathrm{KPa}$. It could be observed from the above Table that most of Indian coal measure rocks are stronger than permissible stress in concrete. Tensile strength is given by $\mathrm{T}=2 \mathrm{~W} /\left(\mathrm{p}^{*} \mathrm{~d}^{*} \mathrm{~L}\right)$, where $\mathrm{W}$-applied load, $\mathrm{d}$ - diameter, L- length of core 
sample. Average strengths of Indian coal measure rocks; tested in Rock Mechanics Laboratory of CIMFR compared to concrete is shown in Table 3.

\subsection{Shaft Lining Methods}

Types and properties of strata determine the shaft lining methods. Mud brick, Cement brick, steel tubbings, monolithic, RCC are the most usual methods. In case of very weak strata, cementation or freezing techniques are applied before lining. For decreasing ventilation resistance in mine shafts, pre-split technique of blasting should be adopted in competent Indian coal measure rocks for smooth round surface and minimum exposure to weak planes.

Shaft lining should be computed from rocks classification, primary and secondary stresses for which Bianiwski formulae are useful. Vertical stress is summation of density*thickness of various beds of rocks or

$\mathrm{V}=\mathrm{C} /\left(\mathrm{k}^{*} \mathrm{n}\right)$ in $\mathrm{KPa}$, for Kilopascals $\left(1 \mathrm{KPa}=10 \mathrm{~kg} / \mathrm{cm}^{2}\right)$;

Where $\mathrm{C}=$ comp. strength in $\mathrm{KPa}, \mathrm{k}=(1-\operatorname{Sin} \mathrm{A}) /(1+\operatorname{Sin} \mathrm{A}), \mathrm{A}$-apparent friction angle $=\operatorname{arc} \tan \mathrm{f}, \mathrm{f}=$ strength factor $=\mathrm{C} / 10$ roughly, $\mathrm{D}$-diameter of shaft in $\mathrm{m}, \mathrm{n}=1 / 2(\mathrm{D}+1)^{1 / 3}$. Horizontal stress is given by $\mathrm{H}=\mathrm{kV}$ and there are other sophisticated electronic stress measurement instruments to check these formulae. For example, calculation for horizontal stress in a $7 \mathrm{~m} \Phi$ shaft works out to $60 \mathrm{KPa}$.

Characteristic Impedance of a medium is given by density*bar wave velocity and from it all other dynamic properties could be determined from geophysical formulae[8]. Approximate values of the above rock properties of European coal measure rocks, including Rock Mass Rating (RMR) as per Rocher are shown in Table 4.

Shotcrete is applied by pressure monitor, with thicker slurry $1: 2$, on the surface to be lined and is different from grouting, which is usually performed, with lean slurry of 1:3, for filling cracks, crevices, inside foundations, rock body around dams etc. by drilling holes and injecting under high pressure, about 12-17 $\mathrm{kN} / \mathrm{m}^{3}$. Batching and mixing plant at surface with water pumped and mixed with cement and other constituents and could be sent down the shaft, through pipeline for applying shotcrete from the suspended scaffold. Shotcrete thickness (t) is based on RSR (Rock Structure Rating), which range from 40 for very hard igneous rocks, to 7 for soft rocks. RSR for sedimentary type coal-measure rocks is around 25 and it is given by: -

$$
\mathrm{t}=\mathrm{D} / 150(65-\mathrm{RSR}) \text { and } \mathrm{RSR}=0.77 * \mathrm{RMR}+12.4
$$

Where, t-thickness of shotcrete in inches, and D-diameter of shaft/ tunnel in ft. RSR could be computed from experimental derivation.

There could be substantial volume of rebound, which could be controlled to $10 \%$ with proper equipment and adjustment (Rispin M, Gause C, Knight B 2004). The velocity could be increased to $100 \mathrm{~m} / \mathrm{s}$ to fill cracks and crevices. The scaffold could be extended by additional sliding plate for reusing immediately by applying manually, with rubber gloves or trowel from the rebounded concrete in the gaps of lining or for smoothening. The shotcrete thickness should be low to prevent cracks and keep the lining flexible and amenable to slight strata movement.

\subsection{Choice of Method}

Shafts can be unlined or partially lined up to rock head with brick wall or RCC. Bad patches are usually strengthened by: -

a) Rock- bolting with wire-netting or steel plates,

b) Tubbing or shaped segments,

c) Cement injection grouting, 
Earlier trials of Shotcrete were with small steel wire or fiber reinforcement, but results of fiber-reinforced applications are encouraging. Shotcrete has been tried successfully in Indian coalmines, where conventional supports failed (Singh UK, Mishra RC.2002) for: -

1) Preventing spalling or collapse of coal pillars,

2) Gallery roof stabilization,

3) Shaft pillar and wall stabilization

Shotcrete method consists of spraying on the wall, at a high pressure, with a nozzle monitor from a hanging scaffold by a mixture of cement, sand, fine stone chips, adhesive resin, quick setting chemicals etc in right proportion. Shotcrete mix can be sent down through pipe from Shotcrete machine mounted on truck from surface.

\subsection{Techno-Economics}

Pre-splitting, using modern technology, Precise and accurate timing delays after blast-hole drilling: This system involves a single row of closely spaced uncharged holes along the neat excavation line. This provides a plane of weakness to which the primary blast can break. It also causes some of the shock waves generated by the blast to be reflected, which reduces shattering and stressing in the finished wall of the host rock.

For lining of smooth pre-split wall, Shotcrete method could be much cheaper, as no shuttering, suspending ropes, winches etc. are required. Thickness of lining will be in the range of 5-10 cm, according to design, as compared to $30 \mathrm{~cm}$ and above thickness for monolithic lining. So, for a designed finished diameter of shaft, less excavated section for drilling and blasting is required.

In order to arrive at a realistic cost benefit by computer simulation in shaft sinking, designed for high capacity winding with rigid guides, with drilling, blasting, mucking and shotcreting, as compared to monolithic concrete lining, different cost components are analyzed with actual field data.

According to sanctioned rates of SKP mine of a coal company, on tender, shaft-sinking cost of relevant items given below, deepening by $41.85 \mathrm{~m}, 4.42 \mathrm{~m}$ diameter; total cost $₹ 14$ million of which rock excavation cost was $₹ 5.08$ million for $1900 \mathrm{~m}^{3}$, coal excavation cost $\mathcal{₹}_{1} .69$ million for $450 \mathrm{~m}^{3}$, compared to arrive at probable cost saving, with shotcreting: -

1) Purchasing and installing 3 winches including shade- $₹$ 1.4 millions+rope- $₹ 3$ millions + power- $₹ 2$ millions + maintenance-₹ 2 millions + shuttering (material + construction)- $₹ 4$ millions $=\bar{₹}_{25}$ millions approx.

2) Monolithic concrete lining- @ $₹ 3,750 / \mathrm{m}^{3}$ approx.

3) Additional excavation for lining @ ₹ $7368 / \mathrm{m}^{3}$ approx.

4) Centering of shuttering and concreting time.

Other extra costs of lining, like concrete mixing plant, pipelines, except shotcreting monitor, are common for both. Similarly, other operations, like installation of winder, scaffold, winches, compressor, substation, and service buildings would be same. Sinking operations like drilling, blasting, excavation, fabrication and fitting of buntons, pipes, cables, ventilation ducting etc. would be same. But, the cycle times would be faster with shotcrete and so there would be more cost saving. Figure 1 displays the section across a vertical shaft for presplit blasting and lining with fiber reinforced shotcrete.

With shotcrete method, additional costs would be: -

1) Drilling of outer blank holes in between charged holes in the outermost trimmer ring of shot holes for pre-split blasting, say ₹ $10 / \mathrm{m}$.

2) Explosive charge per round would be less, as blank holes would join to create free face, viz. Coal Cutting Machine face against solid blasting.

3) Other experimental costs expected, as it would be attempted for the first time in the world for shaft sinking. 


\subsection{Model for Cost Benefit}

Keeping the various variables in view, a computer program was coded, to calculate cost-benefit at different diameters and depths, with shotcrete system, vis-à-vis monolithic lining realistically. Belt Conveyor transport is dangerous at steeper than 1 in 3 gradient and so inclines of 3 times the depth are required at least. The model Flowchart of model program 'scl' is shown in Figure 2.

The model run makes some projections and coded in this program are 'netsave'- expected net saving, 'conlicst'- saving in concrete lining cost, 'exvcst'- saving in excavation cost, 'wincst' - saving in winch and shuttering cost, 'slcst'- shotcrete lining cost, 'diam'- diameter of the finished shaft, 'depth'- of the shaft in m etc. By realistic input of data, a sample program run with different diameters and depths showing the cost benefit by applying shotcrete lining compared to monolithic concrete lining is displayed in E-component.

\section{RESULTS}

Rigid guides in shafts for winding with skips and cages exert additional dynamic strains, which would require more fiber reinforcement and slightly thicker lining. Fiber reinforced shotcrete mix made on the surface, sent down a pipeline, with flexible range at the bottom to be operated by a spraying monitor from the movable suspended scaffold or pit bottom. Great advantage of the shotcrete method of lining is that it could be applied at any level, by moving the scaffold, as no shuttering is required. Wet shotcrete method is expected to be more successful, as dry method will cause lot of air borne dust and health hazard in confined space of a pit.

It could be observed from the program run that approximate cost saving by adopting shotcrete lining, as compared to monolithic concrete lining, is quite considerable and the savings are high for larger size shafts. The salient points of the module are: -

1. In the program run, net savings have been computed, from $₹ 29.38$ million for $5 \mathrm{~m} \Phi, 100 \mathrm{~m}$ depths; to $₹ 59.69$ million, for $7 \mathrm{~m} \Phi, 450 \mathrm{~m}$ depth, compared to conventional monolithic concrete lining in shafts.

2. Cost benefit projected is considerable, even discounting the time saved in lowering of shuttering with thick monolithic concreting.

3. Quick setting chemicals in admixture in shotcrete could help thereby shortening the cycle time of shaft sinking.

\section{DISCUSSIONS}

The first shaft for coal production in India was made at Bogra, in Raneeganj coalfield, of $9 \mathrm{ft}$. diameter, sunk as inevitable mode of entry @ ₹ $2.50 / \mathrm{ft}$, reportedly in 1830 . For deep seams, possibilities were examined for economic and effective alternative safe methods, in view of advances in Rock Mechanics[10]. For example, deepest shafts in India at Kolar Gold fields and even Chinakuri Colliery are only lined up to rock-head and rest shaft is unlined and satisfactorily functioned.

In old shafts, usually such weak zones are being protected by wire netting or steel plating and then by side bolting. Since, rigid guides are mounted on buntons anchored on shaft-walls; dynamic loading and vibrations are transmitted to it, some kind of lining is necessary to prevent bed separation of rocks and spalling or other failures.

But, winding capacity of these shafts are limited to roughly 500 tpd (tonnes per day), in single-tub cages and 900 tpd in tandem cages, as these shafts are provided with rope guides. With higher clearance between cages and walls and high speeds are possible, as also with skip winding.

Measurement of load, stress and strain could be done with Bourdon type Pressure Gauge, Photo-electric transducer, Load cells, Dial gauges, Linear Potentiometer, mechanical Extensometer, electric strain gauge, inductance gauge, tri-axial tests, Creep tests etc. 
Compressive strength is determined on hydraulic Universal Testing Machine, by applying load gradually, till fracture of the sample and is calculated on Max load/x-section of the sample, in $\mathrm{kg} / \mathrm{sq} . \mathrm{cm}$. The accuracy of results depend upon calibration of the machine, end-contact conditions, size and proportion of the test piece, pore fluids, direction of bedding plane, rate of loading, anisotropy, heterogeneity and number of samples tested. Compressive strength could be determined from various other indirect methods like Protodeakonov, drilling rate in stone, in-situ method etc.

In very watery conditions, 'Chemgrout' in liquid form should be sprayed first, which gels quickly and makes the wall, impervious to water. Then, Chemgrout tank with mixer and hoses should be installed on the scaffold. A brand name AM-9, consisting of aqueous solution of Dimethyl Amino-propionitrite and Ammonium Persulphate can be used.

There will be hardly any time lost for lowering and centering of shuttering, as also cement and other material requirement would be roughly $20 \%$ of monolithic method. Cycle time would be drastically reduced and faster progress of sinking and quicker completion of shaft could be easily surmised.

\section{CONCLUSIONS}

Taking into account all these factors, actual cost benefit could be much higher than projected.

1) With Pre-split type of blasting creating smooth round shaft wall, cement consumption would be less.

2) Viable opencast mining reserves are getting exhausted; deeper coal reserves can be more economically exploited by this method of entry.

3) Shotcrete method has been tried in small-scale repair and support in tunnels and pits successfully. So, there is enough reason for Union Ministry to provide S\&T grant for proving viability of the method in complete shaft lining.

4) Once, the technology is proved, there could be much cheaper pits with high winding capacity, which is a limitation in existing pits.

5) With shotcrete lining of high capacity pits and high production machinery, at great depths, the future of underground mining should be bright.

6) With major shaft sinking works shelved for decades could be rescheduled and prioritized by this method

7) With model run of 'scl' will determine the benefit for lowering project construction costs and at the same time increasing production capacity of coal mine projects.

8) The advantages expected of shotcrete lining are: -

a) Planes of weaknesses would not be exposed, smooth shaft-wall

b) Shotcrete lining thickness required would be less

c) No need of shuttering, suspension, centering, required for monolithic lining

d) Shaft-sinking cost and time will be much lesser.

9) The method should be first tried in ventilation pits and rope cage winding pits.

\section{ACKNOWLEDGEMENTS}

Cooperation of scientists of CIMFR, CMPDI, PMI, New Delhi, ISM, Ministry of Coal, IIT, Kharagpur, is acknowledged. The authors are thankful to Dr.D.C.Panigrahi, former Director IIT(ISM) for the opportunity and also Dr.A.B.Samaddar former Director MNIIT for some useful suggestions. Gratitude is expressed to Dr.Rajiv Shekhar, Director IIT(ISM), Dr. R.M.Bhattacharjee, HOD(ME), numerous friends and colleagues.

\section{REFERENCES}

Ahmadi MH, Molladavoodi H, Vásárhelyi B, Davarpanah SM, Dibavar BH. A numerical Investigation of brittle rock fracture mechanism under high rate loading based on a micromechanical damage model; Geotechnical Challenges in Karst; ISRM Specialized Conference, OmišSplit, 2019; Croatia, 11-13.04, ISBN 978-953-95486-8-9 
Amberg F, Tschumi O, Vogel M - US Patent 5,851,580, 1998 - Elastoplastic Model of Rocks with Internal Self-Balancing Stresses. Continuum Approximation, Google Patents

Erasmus WP, Swanepoel CD, Munro D - Shotcrete lining of South Deep shafts, Journal of the SA 2001 - ingentaconnect.com

Girmscheid G, Moser C - Fully automated shotcrete robot for rock support, Computer-Aided Civil and ..., 2001 - Wiley Online Library

Hoek E, Marinos P, Marinos V. Characterization and Engineering Properties of Tectonically Undisturbed by Lithologically Varied Sedimentary Rock Masses; International Journal of Rock Mechanics \& Mining Sciences, 2005; 42/2, 277-285

Hoek E, Diedricks MS. Empirical Estimation of Rock Mass Modulus; International Journal of Rock Mechanics and Mining Sciences, 2006; 43, 203-215

Kumar Dheeraj, Behera PK, Singh UK. Shotcreting in rock excavation and its adhesion strength, Proceedings National Seminar on Problems and Prospects of Bord and Pillar mining in the new millenium, Nov 23-24, 2001 BE, College Kolkata.

Mehmet Sari. Investigating Relationships between Engineering Properties of Various Rock Types; Global Journal of Earth Science and Engineering, 2018; 5, 1-25 1E-ISSN: 2409-5710/18 @ 2018 Avanti Publishers.

Panigrahi DC. Sustainable Mining and Environment - The Indian Context; $4^{\text {th }}$ Asian Mining Congress, 2012; 29-31 January Kolkata, (MGMI)

Revuzhenkoa A. F. and Mikeninaa O.A.; ISSN 1062-7391, Shotcrete spraying process

Journal of Mining Science, 2020, Vol. 56, No. 2, pp. 159-166. () Pleiades Publishing, Ltd., 2020.

Rispin M, Gause C, Knight B -Recent innovations in final lining shotcrete in North American tunneling and mining in Shotcrete, October 2004, Cairns ..., 2004 books.google.com

Samanta BK. Feasibility of Shot Crete Lining in Shafts (with a program in C); Minetech, ISSN: 09707204, Nov-Dec. 1999; Vol.16, No. 1 \& 2, pp 3-12.

Samanta BK, Samaddar AB. Formulation of Coal Mining Projects by Expert System, Journal of Mines, Metals and Fuels, 2002; Books and Journals Private Ltd. Kolkata, pp202.

Samanta BK. Blasting Efficiency and Vibration Damage Control; National Seminar on Explosives and Blasting, 2003; Institution of Engineers (Ind), 6-7 December, DGMS, Dhanbad

Sarkar BN, Samanta BK. Mine Mechanisation with Machine Safety and System Safety; XIII World Congress on Occupational Safety and Health, 1993; New Delhi.

Singh UK. Stabilization of Shaft Pillar by Fibre Reinforced Shotcrete: A Case Study; National Seminar on Geo-mechanics and Ground Control, 2003; 24-25 Sept, CMRI, Dhanbad.

Singh UK and Singh, GSP. "Study of shotcrete support performance in a gate road drivage under high stress condition", Proceedings of the International Conference on Underground Space Technology (ICUST-2011), January 17-19, Bangalore.

Singh.UK, Kumar BK and Munshi B. Effect of temperature on quality of fibre reinforced concrete, $J r$. of Rock Mechanics and Tunneling Tec, V 8, N2, 2002, pp,141-148.

Singh UK, Mishra RC. Steel fibre characterization for reinforcement of shotcrete, Jr. of Rock Mechanics and Tunnelling Tech. Vol. 8, No. 1, 2002, pp. 17- 45.

Singh UK and Basu A Design of fibre-reinforced shotcrete support for coalmine galleries, Mining Technology, 2001 - Taylor \& Francis; Transactions of the Institution of Mining and Metallurgy, V110, Section A, 2001, pp. 183-186.

Sinha Amalendu. R\&D for Sustainable Mining in India- The Way Forward; $4^{\text {th }}$ Asian Mining Congress, 2012; 29-31 January, Kolkata, (MGMI).

Su LJ , Xing XK, Song ZP, Liao HJ - Application of Single Pass Tunnel Lining with Steel Fibre

Reinforced Shotcrete on the Ventilation Shaft of Mount Motian Tunnel-Deep and Underground ..., 2010

- ascelibrary.org

Rock Mechanics Challenges in Underground Construction

https://papers.acg.uwa.edu.au/d/808_83_Kaiser/83_Kaiser.pdf

Techniques of Controlled Blasting

https://www.slideshare.net/sharmapd1/techniques-of-controlled-blasting.

Mining and Blasting

https://miningandblasting.wordpress.com/tag/presplitting/https://doi.org/10.1016/j.ijrmms.2017 .07 .004 ;

Shaft Lining with Shotcrete - Jetcrete $\mathrm{Oz} \quad$ www.jetcrete.com.au > services > 
Figures

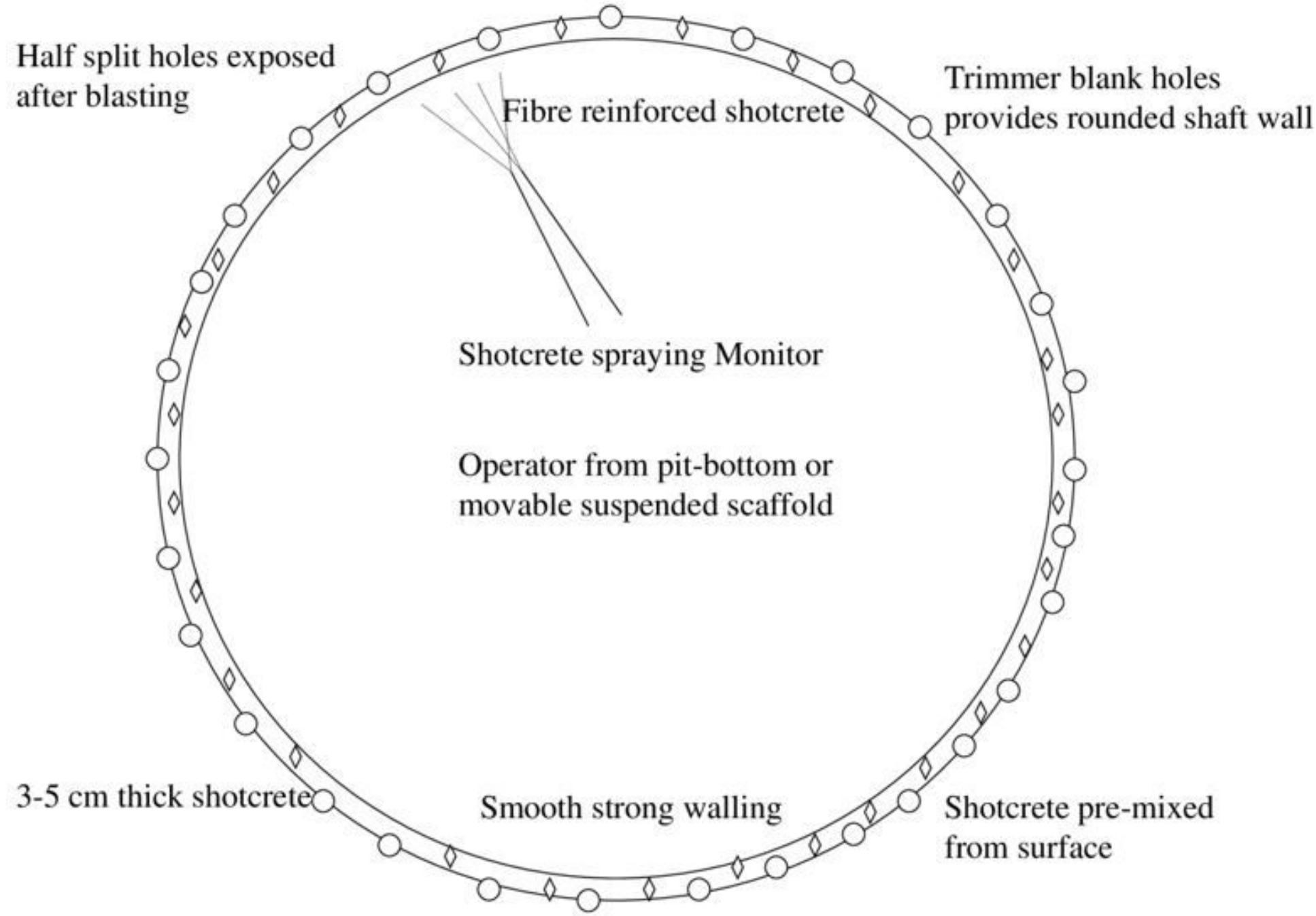

Figure 1

Presplit Blasting \& Shotcrete lining

\section{Image not available with this version}

Figure 2 
The model Flowchart of model program 'scl' is shown in Figure 2.

\section{Supplementary Files}

This is a list of supplementary files associated with this preprint. Click to download.

- TABLEN01.docx

- TABLENO2.docx

- TABLENO3.docx

- TABLENO4.docx

- TABLEN05.docx 